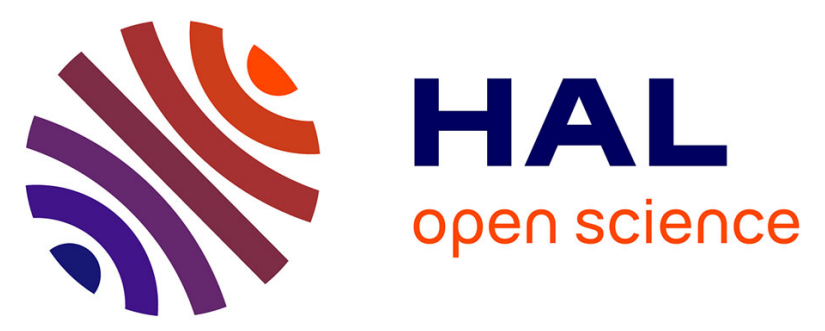

\title{
Airborne lidar measurements of aerosol spatial distribution and optical properties over the Atlantic Ocean during a European pollution outbreak of ACE-2
}

Cyrille Flamant, Jacques Pelon, Patrick Chazette, Vincent Trouillet, Patricia K Quinn, Robert Frouin, Didier Bruneau, Jean-François Leon, Timothy S.

Bates, James R. Johnson, et al.

\section{To cite this version:}

Cyrille Flamant, Jacques Pelon, Patrick Chazette, Vincent Trouillet, Patricia K Quinn, et al.. Airborne lidar measurements of aerosol spatial distribution and optical properties over the Atlantic Ocean during a European pollution outbreak of ACE-2. Tellus B - Chemical and Physical Meteorology, 2000, 52 (2), pp.662-677. 10.3402/tellusb.v52i2.17126 . hal-01637666

\section{HAL Id: hal-01637666 https://hal.science/hal-01637666}

Submitted on 17 Nov 2017

HAL is a multi-disciplinary open access archive for the deposit and dissemination of scientific research documents, whether they are published or not. The documents may come from teaching and research institutions in France or abroad, or from public or private research centers.
L'archive ouverte pluridisciplinaire HAL, est destinée au dépôt et à la diffusion de documents scientifiques de niveau recherche, publiés ou non, émanant des établissements d'enseignement et de recherche français ou étrangers, des laboratoires publics ou privés. 


\section{Airborne lidar measurements of aerosol spatial distribution and optical properties over the Atlantic Ocean during a European pollution outbreak of ACE-2}

Cyrille Flamant, Jacques Pelon, Patrick Chazette, Vincent Trouillet, Patricia K. Quinn, Robert Frouin, Didier Bruneau, Jean François Leon, Timothy S. Bates, James Johnson \& John Livingston

To cite this article: Cyrille Flamant, Jacques Pelon, Patrick Chazette, Vincent Trouillet, Patricia K. Quinn, Robert Frouin, Didier Bruneau, Jean François Leon, Timothy S. Bates, James Johnson \& John Livingston (2000) Airborne lidar measurements of aerosol spatial distribution and optical properties over the Atlantic Ocean during a European pollution outbreak of ACE-2, Tellus B:

Chemical and Physical Meteorology, 52:2, 662-677, DOI: 10.3402/tellusb.v52i2.17126

To link to this article: http://dx.doi.org/10.3402/tellusb.v52i2.17126

$$
\begin{aligned}
& \text { (c) } 2000 \text { The Author(s). Published by Taylor \& } \\
& \text { Francis. }
\end{aligned}
$$

\section{曲 Published online: 15 Dec 2016.}

Submit your article to this journal ๔

Џll Article views: 12 


\title{
Airborne lidar measurements of aerosol spatial distribution and optical properties over the Atlantic Ocean during a European pollution outbreak of ACE-2
}

\author{
By CYRILLE FLAMANT ${ }^{1 *}$, JACQUES PELON ${ }^{1}$, PATRICK CHAZETTE ${ }^{2}$, VINCENT \\ TROUILLET $^{1}$, PATRICIA K. QUINN ${ }^{3}$, ROBERT FROUIN ${ }^{4}$, DIDIER BRUNEAU ${ }^{1}$, JEAN \\ FRANÇOIS LEON ${ }^{2}$, TIMOTHY S. BATES ${ }^{3}$, JAMES JOHNSON ${ }^{3}$ and JOHN LIVINGSTON ${ }^{5},{ }^{1}$ Service \\ d'Aéronomie, CNRS-UPMC-UVSQ, Paris, France; ${ }^{2}$ Laboratoire des Sciences du Climat et de \\ l'Environnement, CEA-CNRS, Gif-sur-Yvette, France; ${ }^{3}$ Pacific Marine Environment Laboratories, NOAA, \\ Seattle, WA, USA $;{ }^{4}$ Scripps Institution of Oceanography, La Jolla, CA, USA $;{ }^{5}$ SRI International, Menlo Park,
} $C A, U S A$

(Manuscript received 15 April 1999; in final form 13 September 1999)

ABSTRACT

Airborne lidar measurements of the aerosol spatial distribution and optical properties associated with an European pollution outbreak which occured during the Second Aerosol Characterization Experiment (ACE-2) are presented. Size distribution spectra measured over the ocean near Sagres (Portugal), on-board the Research Vessel Vodyanitsky and on-board the Avion de Recherche Atmosphérique et Télédétection (ARAT) have been used to parameterize the aerosol vertical distribution. This parameterization, which is essential to the analysis of airborne lidar measurements, has been validated via closure experiments on extinction coefficient profiles and aerosol optical depth (AOD). During the studied event, AOD's retrieved from lidar measurements at $0.73 \mu \mathrm{m}$ range between 0.055 and 0.10 . The parameterized aerosol vertical distribution has been used to shift AOD retrievals from 0.73 to $0.55 \mu \mathrm{m}$ to enable comparison with other remote sensing instruments. At the latter wavelength, AOD's retrieved from lidar measurements range between 0.08 and 0.14 . An agreement better than $20 \%$ is obtained between AOD's derived from lidar and sunphotometer measurements made at the same time and place over the ocean near the coast. However, large differences are observed with the AOD estimated from Meteosat imagery in the same area. These differences are thought to be caused by large uncertainties associated with the Meteosat sensitivity for small AOD's or by the presence of thin scattered clouds. Lidar-derived particulate extinction profiles and scattering coefficient profiles measured by a nephelometer mounted on the ARAT, in a different part of the plume, were found in good agreement, which could be an indication that absorption by pollution aerosols is small and/or that soot is present in small amounts in the European pollution plume. Lidar measurements have also been used to differentiate the contribution of different aerosol layers to the total AOD. It is shown that the AOD in the marine atmospheric boundary layer (MABL) can contribute as much as $70 \%$ of the total AOD in some regions. At $0.73 \mu \mathrm{m}$, the AOD in the continental plume was observed to diminish with the distance to the coastline from 0.04 to 0.03 .

* Corresponding author. Service d'Aéronomie du CNRS, Tour 15, Boîte 102, Université Pierre et Marie Curie, 4 Place Jussieu, 75252 Paris Cedex 05, France.

e-mail: cyf@aero.jussieu.fr. 


\section{Introduction}

An accurate determination of the optical and microphysical properties of anthropogenic and natural aerosols at the global scale is necessary to assess their overall direct and indirect radiative forcing (Boucher and Lohman, 1995; Tegen and Lacis, 1996). This is particularly true in the vertical and over the ocean where measurements are sparse.

To this respect, cooperative campaigns have been recently developed to characterize the microphysics and chemical and radiative properties of particles in continental aerosol outbreaks. The first Aerosol Characterization Experiment (ACE-1) was held at the end of 1995 over the Southwest Pacific Ocean in clear marine conditions (Bates et al., 1998). Heavily polluted conditions were analyzed over the western Atlantic Ocean during the Tropospheric Aerosol Radiative Forcing Observational eXperiment (TARFOX) campaign (Russell et al., 1999). The Second Aerosol Characterization Experiment (ACE-2, Raes et al., 2000; Heintzenberg and Russell, 2000), has been deployed over the eastern Atlantic Ocean, between southern Portugal and the Canary Islands, to study the radiative effects and controlling processes of anthropogenic aerosol outbreaks from Europe as they are transported over the eastern Atlantic Ocean. Emphasis was put on the assessment of the aerosol radiative impact through closure experiments involving measurements and modeling (Heintzenberg and Russell, 2000). In these campaigns, most of the analyses coupling microphysical and optical properties of the aerosol particles have been made in the atmospheric surface layer from instrumented ships. Provided that more analyses could be undertaken in the vertical over wide areas, they would improve our understanding of aerosol and cloud related processes such as sedimentation, dispersion and transport, which are important to establish the Earth's energy budget.

Airborne laser remote sensing instruments have the capability to characterize optical properties of particle on both the vertical and horizontal (Browell et al., 1996, Flamant et al., 1998), therefore being relevant tools for dust and continental plume outbreak survey studies. Lidars also have the potential to make measurements at the global scale from space (Winker et al., 1996).
The lidar signal depends on the particulate backscatter and extinction (scattering plus absorption) coefficients. However, retrieving the extinction coefficient from single-wavelength nadir lidar measurements requires the knowledge of the backscatter to extinction ratio which depends on the aerosol characteristics (aerosol size distribution and composition). The determination of particle optical properties from single wavelength lidar measurements thus calls for closure experiments.

In this paper, we will present results obtained during ACE-2 with the French airborne lidar LEANDRE 2 (Quaglia et al., 1996) operating at a wavelength of $0.73 \mu \mathrm{m}$. The objectives of this paper are twofold:

- to develop and validate a method for retrieving particulate extinction profiles from lidar measurements in polluted coastal areas,

- to characterize, using LEANDRE 2, the changes in the optical properties of a polluted air mass over the Atlantic Ocean during the continental aerosol outbreak of 6 July 1997 (Verver et al., 2000).

An overview of the synoptic setting and Avion de Recherche Atmosphérique et de Télédétection (ARAT) flight missions on 6 July 1997 is provided in Section 2. In this section, we also present the evolution of the aerosol spatial distribution, as a function of the distance to the shoreline, as observed by LEANDRE 2. In Section 3, we introduce the measurements and methodologies used to derive particulate extinction coefficient profiles from lidar data. In Section 4, we report on clear sky column closure experiments using lidarderived and nephelometer particulate extinction coefficient profiles as well as optical depth (AOD) measurements made by a sunphotometer and by Meteosat. In Section 5, we discuss the evolution, as a function of the distance to the shoreline, of the lidar-derived AOD in the continental plume, before concluding in Section 6 .

\section{Synoptic setting and experimental set-up on the 6 July 1997 CLEARCOLUMN missions}

On 6 July 1997, the presence of a surface high pressure centered west of Brittany resulted in an outbreak of European pollution over the ACE-2 


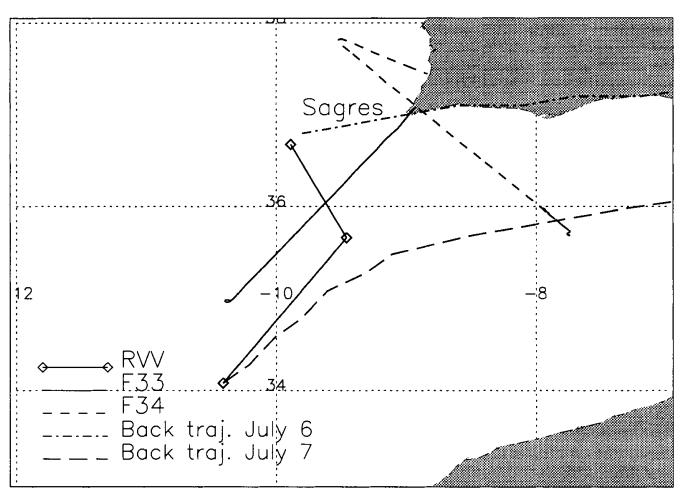

Fig. 1. ARAT flight tracks during CLEARCOLUMN flight missions F33 and F34 on 6 July 1997 (solid and dashed lines, respectively). Also shown is the Research Vessel Vodyanitsky (RVV) heading from 6 July at 1200 UTC to 7 July at 1200 UTC (open symbols). KNMI back trajectories ending at the location of the ship on 6 and 7 July (at 1200 UTC) are figured by the dot-dashed and long-dashed lines, respectively.

experimental area (Verver et al., 2000). The Royal Netherlands Meteorological Institute (KNMI) model back trajectories (Scheele et al., 1996) indicate that the flow in Sagres and over the coastal Atlantic ocean (at least within $300 \mathrm{~km}$ from the Portuguese coastline) was from the north-northeast in the lower $3 \mathrm{~km}$ of the troposphere (Fig. 1).

Measurements of the optical, thermodynamical and structural properties of the continental plume near Sagres have been made from two platforms: the ARAT and the Research Vessel Vodyanitsky (RVV). On 6 July at 1200 UTC, the RVV was located west of Sagres and headed south (Fig. 1). ARAT flight mission 33 consisted of a round trip along the RVV heading (from 0900 to 1100 UTC). ARAT flight mission 34 was designed to document the continental plume in the cross-flow direction (from 1900 to 2200 UTC). From now on, flights 33 and 34 will be referred to as F33 and F34. F33 and F34 tracks are shown in Fig. 1.

The RVV had balloon lauching capabilities, and carried twin differential mobility particle sizers (DMPS), a nephelometer, an aerodynamic particle sizer (APS) and the NASA Ames Airborne Tracking 6-channel Sunphotometer (AATS-6) among other instruments. A hand-held 5-channel radiometer, SIMBAD, was used to measure both water-leaving radiance and solar beam transmis- sion. The ARAT carried the lidar LEANDRE 2 and was equipped with standard in situ sensors and sensors dedicated to the analysis of aerosol properties (nephelometer, particle and cloud condensation nuclei counters) and radiative fluxes (upward and downward pyranometers and pyrgeometers) (Chalon et al., 1998).

The knowledge of the $\mathrm{RH}$ field in the lower troposphere is crucial for lidar data analysis. Three soundings performed on-board the Research Vessel Vodyanitsky (RVV) between 6 July 1997 (1200 UTC) and 7 July 1997 (1200 UTC) have been used to map out the vertical structure of temperature and $\mathrm{RH}$ along the ARAT flight track for F33 (Figs. 2, 3, respectively). Even though not performed at the same time and place, the temper-

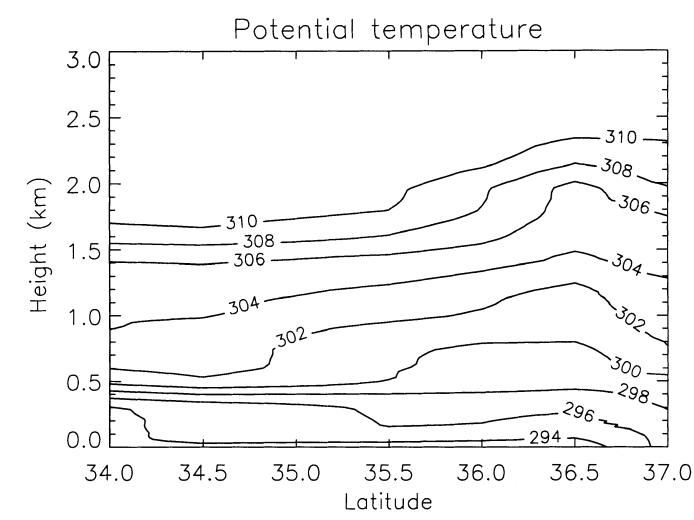

Fig. 2. Potential temperature structure above the Atlantic Ocean near Sagres (Portugal) on 6 and 7 July 1997 as derived from balloon soundings lauched from the RVV.

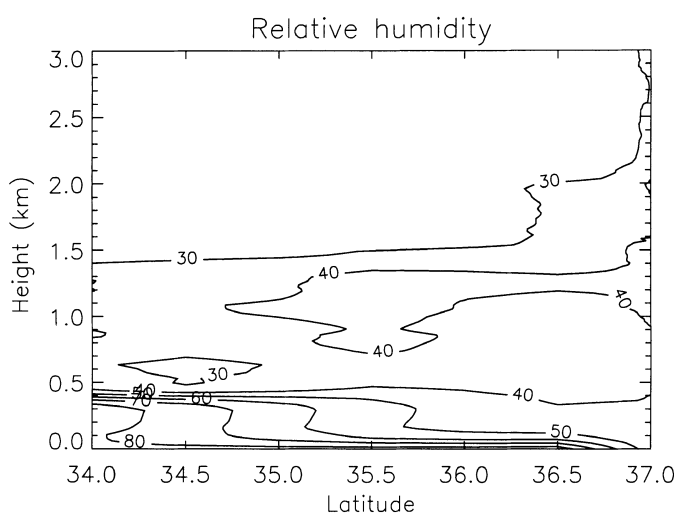

Fig. 3. Same as Fig. 2, but for relative humidity (RH). 
ature and RH structure depicted by the balloon soundings and the atmospheric reflectivity depicted by LEANDRE 2 were very similar as we show now. Therefore, we have used these $\mathrm{RH}$ soundings for our lidar data analysis.

The most stricking feature in the temperature and RH fields observed along the track of the ship is the sudden thickening of the marine atmospheric boundary layer (MABL) at about $35.75^{\circ} \mathrm{N}$ and the associated heating and moistening in the MABL. The top of the MABL is generally marked by a temperature inversion as well as a large $\mathrm{RH}$ gradient. The MABL can in turn be separated into (i) the MABL mixed layer which is generally characterized by constant values of potential temperature and $\mathrm{RH}$, and (ii) the surface layer (between the oceanic surface and the mixed layer) which is characterized by large gradients of potential temperature and $\mathrm{RH}$.

As it is advected over the ocean, the flow above the MABL experiences subsidence as shown by the sloping isothermals (it is also observed from the KNMI back trajectories). This subsidence reinforces a second (synoptic) temperature inversion at an altitude of $1.5 \mathrm{~km}$ (Fig. 2).

The evolution of the lidar-derived particulate extinction coefficient (LPEC) at $0.73 \mu \mathrm{m}$ obtained from LEANDRE 2 in the lower troposphere during F33 is shown in Fig. 4. The vertical extent of the continental plume is maximum over land (Sagres is located on the right, near $37^{\circ} \mathrm{N}$ ) and reaches $2 \mathrm{~km}$. The depth of the aerosol plume decreases over the ocean as a result of subsidence.

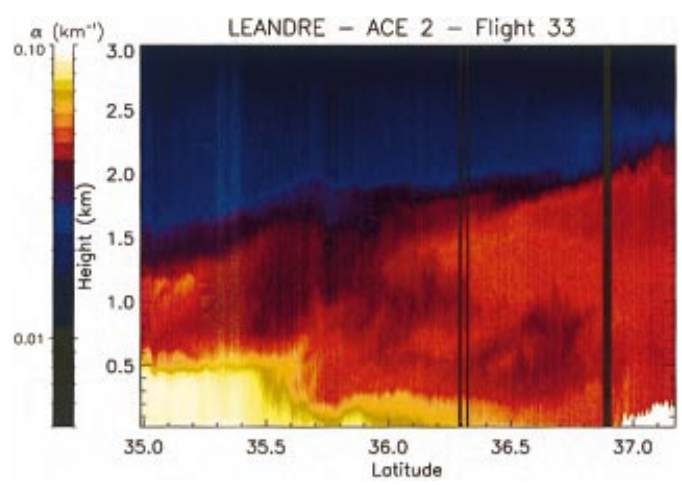

Fig. 4. Lidar-derived particulate extinction coefficient for flight mission F33 on 6 July 1997 between 0900 and 1000 UTC.
As expected from the flow structure analysis, both the depth of the MABL and the LPEC in the MABL increase significantly at about $35.75^{\circ} \mathrm{N}$. [Once they have been stripped from the surface, aerosol particles are trapped in the mixed layer by the temperature inversion capping the atmospheric boundary layer, in which case lidar-derived atmospheric extinction is generally observed to be large in the mixed layer and to decrease rapidly above as particles are trapped by the capping inversion (see for example Flamant et al., 1998 and Johnson et al., 2000).] The MABL depth (as derived from lidar measurements) is on the order of 0.01 to $0.02 \mathrm{~km}$ near the shoreline. It increases steadily from 0.02 to $0.2 \mathrm{~km}$ between 37 and $35.75^{\circ} \mathrm{N}$, before reaching $0.5 \mathrm{~km}$ near $35.5^{\circ} \mathrm{N}$.

The evolution of the LPEC during F34 is shown in Fig. 5. The depth of the plume over Sagres (at $37^{\circ} \mathrm{N}$ ) is nearly equal to the one observed during F33 $(2 \mathrm{~km})$. The maximum vertical extent of the plume steadily decreases from 2.5 to $1.5 \mathrm{~km}$ as the aircraft flies south. It is observed to be rather inhomogeneous both in the vertical and in the horizontal. We also observe an elevated layer characterized by enhanced extinction between 35.8 and $36.5^{\circ} \mathrm{N}$. It is separated from the subsiding European continental plume by a clear layer as evidenced by the smaller extinction coefficient values. Back trajectories (calculated with TM2Z, Ramonet and Monfray (1996)) indicate the presence of desert dust at an altitude of about $2.5 \mathrm{~km}$ in that region.

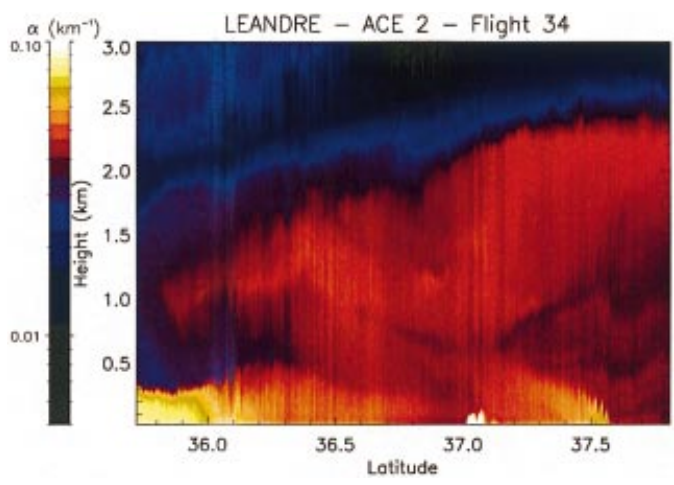

Fig. 5. Lidar-derived particulate extinction coefficient for flight mission F34 on 6 July 1997 between 1930 and 2100 UTC. 


\section{Lidar-derived particulate extinction coefficient}

For the sake of clarity, we have presented the spatial distribution of the aerosol in the continental plume using LPEC profiles in the previous section. The procedure used to derive extinction coefficient profile from lidar measurements is now detailed.

Particulate extinction coefficients are derived from the lidar signal via an inversion procedure (Klett, 1985; Flamant et al., 1998). This procedure consists in solving the lidar equation for the particle extinction and backscatter coefficients (2 unknowns). It requires the knowledge of the particulate backscatter-to-extinction ratio (BER) profile and a reference value of the extinction coefficient. Both of these parameters essential to the lidar inversion can be obtained independently.

The BER profile can be modeled provided that one is able to identify (i) the diameters and refractive indices (including their dependence on $\mathrm{RH}$ ) of the different types of particles composing the aerosol, (ii) their number concentration and (iii) the evolution of all these parameters with altitude. To do so, we have used in situ aerosol size distribution measurements.

In the particular case of LEANDRE 2, the reference scattering coefficient is measured at $0.55 \mu \mathrm{m}$ by a nephelometer mounted on the ARAT. At the ARAT flight level, we have assumed the aerosol population essentially consists of watersoluble particles (see Subsection 3.1). The absorption generally associated with such particles is small and we have presumed the extinction coefficient to be equal to the scattering coefficient.

\subsection{Characterization of the aerosol vertical distribution}

In the event of a continental plume outbreak, the coastal marine aerosol is a dynamic reservoir of particles originating from diverse marine and continental sources. Sea-salt, dust, water-solubles (sulphate, nitrate), particulate organic matter (POM) and soot can be important contributors to the coastal marine aerosol composition. The coastal aerosol number concentration distribution generally exhibits a coarse mode dominated by aged sea-salt and/or dust and a fine mode populated by water-solubles, POM and soot, but not necessarly dominated by sulphate (Hegg et al., 1997). Soot can be a significant contributor to the fine mode in some regions and can have a significant impact on aerosol optical properties due to its light-absorbing properties.

Water-soluble, POM and soot particles have comparable modal diameters (Boucher and Anderson, 1995; B. Anderson et al., 1996; Berner et al., 1996). The refractive indices of water-solubles and POM particles are also very similar (Sloane, 1984; Holben et al., 1991), whereas that of soot is quite different (Berner et al., 1996).

Submicron massic concentrations of 1.1, 2.8 and $5.2 \mu \mathrm{g} \mathrm{m}^{-3}$ for soot, POM and sulphate, respectively, were measured on the RVV (Quinn et al., Novakov et al., 2000) on 6 July. Therefore, soot only represents $12 \%$ of the total submicronic mass at the surface and, as a first approximation, its contribution has been neglected. We shall come back later to this assumption. The total submicron massic concentration $\left(10.1 \mu \mathrm{g} \mathrm{m}^{-3}\right)$ measured on the RVV was also found in excellent agreement with that measured in Sagres on 6 July (Neusüß et al., 2000).

In the following, we have considered an equivalent type of particle characterized by an equivalent refractive index (equal to that of POM and watersolubles particles) and an equivalent modal diameter. This mode (or these modes) will further be referred to as pollution aerosol mode(s).

3.1.1. Measurements. In this study, we have assumed the different modes could be discribed by lognormal distributions. The modal diameters, dispersions and number concentrations of pollution aerosol and sea-salt particles, at a given level of the atmosphere, are obtained by fitting up to four lognormal distribution to the aerosol size distribution measurements. The associated refractive indices are taken from the literature (Table 1).

Above an altitude of $100 \mathrm{~m}$, modal diameters, dispersions and number concentrations are obtained from a Particle Measuring System (PMS) Active Scattering Aerosols Spectrometer Probe (ASASP) mounted on the ARAT which provided continuous aerosol size distributions for particles with diameters comprised between 0.12 and $3.12 \mu \mathrm{m}$ (Fig. 6) near Sagres during the take-off of F33 and F34. Near the oceanic surface, these parameters are obtained from twin DMPS and APS data converted from $55 \% \mathrm{RH}$ to $5-10 \% \mathrm{RH}$ 
Table 1. Aerosol characteristics at different levels in the vicinity of Sagres on 6 July 1997

\begin{tabular}{|c|c|c|c|c|c|c|c|c|}
\hline \multirow[b]{2}{*}{$\begin{array}{l}\text { Type of } \\
\text { aerosol }\end{array}$} & \multirow[b]{2}{*}{$\begin{array}{l}\text { diameter } \\
(\mu \mathrm{m})\end{array}$} & \multicolumn{2}{|c|}{ DMPS-APS (10 m) } & \multicolumn{2}{|c|}{ ASASP F33 (114 m) } & \multicolumn{2}{|c|}{ ASASP F33 $(3160 \mathrm{~m})$} & \multirow[b]{2}{*}{$\begin{array}{l}\text { Dry refractive } \\
\text { index }\end{array}$} \\
\hline & & $\begin{array}{c}\text { Dispersion } \\
(\mu \mathrm{m})\end{array}$ & $\begin{array}{l}\text { Conc. } \\
\left(\# \mathrm{~cm}^{-3}\right)\end{array}$ & $\begin{array}{c}\text { dispersion } \\
(\mu \mathrm{m})\end{array}$ & $\begin{array}{c}\text { conc. } \\
\left(\# \mathrm{~cm}^{-3}\right)\end{array}$ & $\begin{array}{l}\text { dispersion } \\
(\mu \mathrm{m})\end{array}$ & $\begin{array}{l}\text { conc. } \\
\left(\# \mathrm{~cm}^{-3}\right)\end{array}$ & \\
\hline pollution & 0.08 & 1.4 & 6000 & - & - & - & - & $1.53-j 5 \cdot 10^{-4}$ \\
\hline pollution & 0.11 & 1.4 & 8000 & 1.3 & 1650 & 1.2 & 115 & $1.53-j 5 \cdot 10^{-4}$ \\
\hline pollution & 0.22 & 1.4 & 800 & 1.4 & 450 & 1.3 & 11.5 & $1.53-j 5 \cdot 10^{-4}$ \\
\hline sea-salt & 0.8 & 2.0 & 13 & 1.5 & 17 & - & - & $1.38-j 1.1 \cdot 10^{-6}$ \\
\hline
\end{tabular}

Modal diameters, dispersions and number concentrations are derived by fitting up to 4 lognormal distributions to measured aerosol size distributions. All parameters are given for a RH less than $10 \%$.

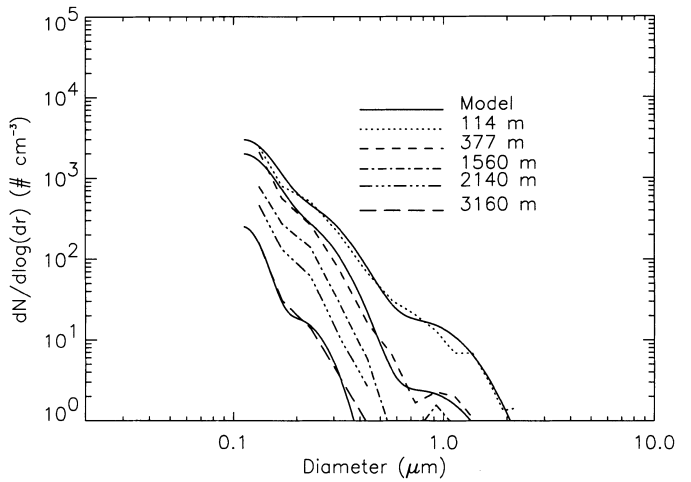

Fig. 6. Aerosol size distribution in the lower troposphere on 6 July as measured by the particle measuring system (PMS), active scattering aerosol spectrometer probe (ASASP) mounted on the avion de recherche et Télédétection (ARAT) during the ascent of F33. The solid lines correspond to the best fit obtained with the modeled size distribution.

(Quinn et al.; Bates et al., 2000). The resulting composite spectra provided aerosol size distributions for particles with diameters ranging from 0.00453 to $3.061 \mu \mathrm{m}$ (Fig. 7). DMPS-APS measurements closest in time to the ASAPS profiles (between 0900 and 1100 UTC on 6 July) will be used.

In the MABL, the measurements show the existence of four modes (Table 1). Three pollution aerosol modes are identified at 0.08, 0.11 and $0.22 \mu \mathrm{m}$. The two first modes together can be considered as the "Aitken mode". The third mode corresponds to the "accumulation mode". The mode corresponding to aged (stationary) sea-salt particles is observed at $0.8 \mu \mathrm{m}$. "Aged" sea-salt particles (as opposed to "fresh" sea-salt particles) result from the action of the average SWS over

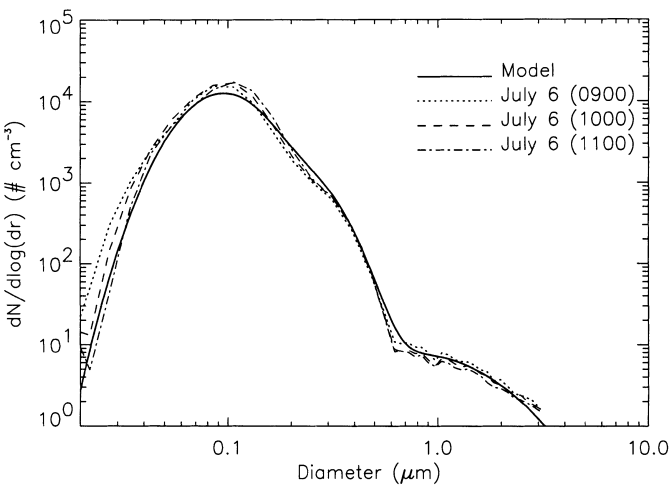

Fig. 7. Aerosol size distribution in the marine atmospheric boundary layer (MABL) on 6 July at 0900, 1000 1nd 1100 UTC (dotted, dashed and dot-dashed lines, respectively) as measured on-board the RVV. The solid line correspond to the best fit obtained with the modeled size distribution which characteristics are given in Table 1.

the previous $12 \mathrm{~h}$ (Hoppel et al., 1990). "Fresh" sea-salt particles are generated by both surface tearing and bubble mediated production (Smith et al., 1989) and result from an "instantaneous action" of surface wind speed (SWS). They generally have a much larger diameter than "aged" seasalt particles.

Above the MABL, given the sampling range of the ASASP, we only observe the $0.11,0.22$ and $0.8 \mu \mathrm{m}$ modes. Note that, even though the mode may not be entirely sampled because of instrumental limitations, number concentrations derived by fitting lognormal distributions to measured aerosol size distributions are not affected by this limitation. However, uncertainties on the number concentration values so retrieved are likely to be large. The number concentrations profiles 
measured in the $0.11,0.22$ and $0.8 \mu \mathrm{m}$ modes are shown by Fig. 8 .

3.1.2. Parameterization. To model the BER profile (see Subsection 3.2), we have parameterized the number concentration in each mode as a function of altitude (Fig. 8). This parametrization is detailed in Section 8 and only briefly discussed here. At the wavelength of $0.73 \mu \mathrm{m}$, the contribution of the $0.08 \mu \mathrm{m}$ mode to the total extinction coefficient in the MABL was calculated to be of the order of (or less than) the molecular contribution. We have discarded this mode in the parameterization. DMPS-APS measurements are used to characterize the aerosol number concentrations in the oceanic. Above the, in the MABL, aerosol number concentrations are assumed constant and derived from ASASP measurements made near the top of the MABL. Above the MABL, the total number concentration in a given mode is separated in a "background" component and a "plume" component. The "background" number concentration component is parameterized as exponentially decreasing with altitude between the top of the MABL and $3 \mathrm{~km}$ (the range of altitude over which the lidar signal is processed) according to Jaenicke (1993). The "plume" number concentration component is parameterized as exponentially decreasing with altitude between the MABL top and the top of the plume. Information of the

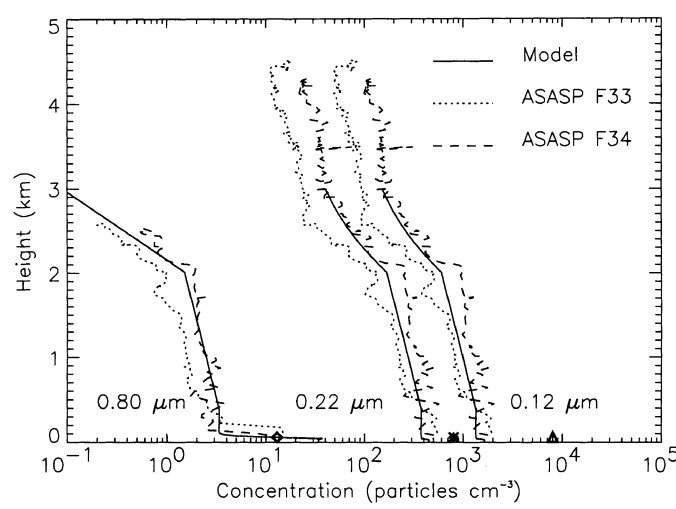

Fig. 8. Number concentration profiles of particles in the $0.11,0.22$ and $0.8 \mu \mathrm{m}$ modes as derived from ASASP measurements made during the ascent of F33 and F34. The surface number concentration values measured at $10 \mathrm{~m}$ on the RVV are reported as a triangle, an asterisk and a lozenge for the $0.11,0.22$ and $0.8 \mu \mathrm{m}$ modes, respectively. average MABL depth and top of the plume, as well as their evolution with the distance from the coastline, are derived from lidar measurements.

The presence of fresh sea-salt particles over the ocean is to be expected even though it is not observed on DMPS-APS size distributions. Their modal diameter and dispersion are taken from von Hoyningen-Huene et al. (1998) (i.e., 2.8 and $1.5 \mu \mathrm{m}$, respectively). They are assumed to be present in the MABL only. To assess their number concentration near Sagres, we have used AATS-6 measurements of the AOD made at 0.525 and $0.864 \mu \mathrm{m}$ on 6 July 1997 (from 0800 to 1200 UTC). We derive an equivalent Angstrom coefficient, $\tilde{\delta}$, between 0.525 and $0.864 \mu \mathrm{m}$ which is then used to constrain the number concentration parameterization in the lower troposphere (Section 9). The fresh sea-salt particle number concentration in the MABL is tuned until the parameterized equivalent Angstrom coefficient matches the one derived from the sunphotometer measurements at ambient $\mathrm{RH}$. For further validation, the parameterized equivalent Angstrom coefficient is compared to the equivalent Angstrom coefficient derived (between 0.55 and $0.7 \mu \mathrm{m}$ ) from scattering coefficients measurements made by nephelometer (located on the RVV) at 55\% RH (Quinn et al., 2000).

Near Sagres, an average value of $\tilde{\delta}=1.31$ (at ambient $\mathrm{RH}$ ) is obtained from the AATS- 6 measurements closest in time and location to the lidar data. We derive a "fresh" sea-salt number concentration of 5.5 particles $\mathrm{cm}^{-3}$ (Table 2). At 55\% $\mathrm{RH}$, the equivalent Angstrom coefficients derived from the aerosol model and from nephelometer measurements are in good agreement (1.61 and 1.48 , respectively).

We have also compared the fresh sea-salt particle number concentration value with those derived from the relationship between SWS and the number concentration of particles in the 2-4 $\mu \mathrm{m}$ range proposed by Smith et al. (1989). When applied to our data (SWS between 6 and $8 \mathrm{~m} \mathrm{~s}^{-1}$ ), it yields a number concentration of approximately 1 particles, $\mathrm{cm}^{-3}$, in poor agreement with what we obtain. Our higher "fresh" sea-salt number concentration values could be due wave breaking in the shallow coastal waters which is not accounted for in the relationship of Smith et al. (1989). In these regions, wave breaking would generate a large amount of particles of 
Table 2. Parameters driving the vertical distribution of aerosol number concentration in the coastal region of Sagres on 6 July 1997

\begin{tabular}{|c|c|c|c|c|c|c|c|c|c|}
\hline Aerosol & $\begin{array}{c}N_{\mathrm{sfl}} \\
\left(\# \mathrm{~cm}^{-3}\right)\end{array}$ & $\begin{array}{c}H_{\mathrm{sfl} 1} \\
\left(\mathrm{~km}^{-1}\right)\end{array}$ & $\begin{array}{c}N_{\mathrm{MABL}} \\
\left(\# \mathrm{~cm}^{-3}\right)\end{array}$ & $\begin{array}{c}H_{\mathrm{MABL}} \\
\left(\mathrm{km}^{-1}\right)\end{array}$ & $\begin{array}{c}N_{\text {Back }}^{0} \\
\left(\# \mathrm{~cm}^{-3}\right)\end{array}$ & $\begin{array}{c}H_{\text {Back }} \\
\left(\mathrm{km}^{-1}\right)\end{array}$ & $\begin{array}{c}N_{\text {Plume }}^{0} \\
\left(\# \mathrm{~cm}^{-3}\right)\end{array}$ & $\begin{array}{c}H_{\text {Plume }}^{0} \\
\left(\mathrm{~km}^{-1}\right)\end{array}$ & $\begin{array}{c}H_{\mathrm{T}} \\
\left(\mathrm{km}^{-1}\right)\end{array}$ \\
\hline & \multicolumn{9}{|c|}{ Close to Sagres $\left(37^{\circ} \mathrm{N}, 9^{\circ} \mathrm{W}\right)$} \\
\hline pollution $(0.11 \mu \mathrm{m})$ & 8000 & 0.01 & 1650 & 0.01 & 575 & 2.0 & 1035 & 2.0 & 0.25 \\
\hline pollution $(0.22 \mu \mathrm{m})$ & 800 & 0.01 & 450 & 0.01 & 150 & 2.0 & 300 & 2.0 & 0.25 \\
\hline sea-salt $(0.8 \mu \mathrm{m})$ & 17 & 0.01 & 17 & 0.01 & - & - & 4 & 2.0 & 0.25 \\
\hline \multirow[t]{2}{*}{ sea-salt $(2.8 \mu \mathrm{m})$} & 5.5 & 0.01 & 5.5 & 0.01 & - & - & - & - & - \\
\hline & \multicolumn{9}{|c|}{$250 \mathrm{~km}$ from Sagres $\left(35^{\circ} \mathrm{N}, 10.5^{\circ} \mathrm{W}\right)$} \\
\hline pollution $(0.11 \mu \mathrm{m})$ & 2000 & 0.01 & 600 & 0.1 & 300 & 8.0 & 700 & 2.0 & 0.25 \\
\hline pollution $(0.22 \mu \mathrm{m})$ & 800 & 0.01 & 100 & 0.1 & 100 & 8.0 & 100 & 2.0 & 0.25 \\
\hline sea-salt $(0.8 \mu \mathrm{m})$ & 10 & 0.01 & 10 & 0.1 & - & - & 2 & 2.0 & 0.25 \\
\hline sea-salt $(2.8 \mu \mathrm{m})$ & 1 & 0.01 & 1 & 0.1 & - & - & - & - & - \\
\hline
\end{tabular}

supermicronic size, even though the SWS is less than $10 \mathrm{~m} \mathrm{~s}^{-1}$.

Note that the combination of aerosol characteristics (modal diameter, dispersion, refractive index), number concentration and height scales proposed in this study (and summarized in Table 2) is one possible solution. It may not be the true solution.

\subsection{Determination of the particulate backscatter- to-extinction ratio profile}

The particulate BER is defined by

$\phi_{\mathrm{p}}(\lambda, z)=\frac{\sum_{i} f^{i}(z) \beta_{\mathrm{p}}^{i}(z)}{\sum_{i} f^{i}(z) \alpha_{\mathrm{p}}^{i}(z)}$,

with

$\sum_{i} f^{i}(z)=1 \quad \forall z$,

where $\alpha_{\mathrm{p}}^{i}$ and $\beta_{\mathrm{p}}^{i}$ are the particulate extinction and backscatter coefficient in mode $i$, respectively and $f^{i}$ represents the fraction of aerosol in mode $i$.

The modal diameters and refractive indices of the particles composing the aerosol are fed into a Mie code (for spherical particles) to derive the extinction and backscatter cross-sections associated with each type of particle. The information on the number concentration in each mode is then used to calculate the total particulate backscatter and extinction coefficients and in turn the BER.

The marine aerosol is hygroscopic. Sea-salt and water-solubles particles diameters increase and their refractive indices decrease with increasing RH (see for example Flamant et al., 1998). Their evolution as a function of $\mathrm{RH}$ is modeled on the basis of Hänel's (1976) work. The growth factor calculated using Hänel's model is equal to 1.225 at $60 \%$ RH. At the same RH, Neusüß et al. (2000) report size-segregated hygroscopic growth factors ranging from 1.18 to 1.25 for particle diameters ranging from 0.05 to $3.5 \mu \mathrm{m}$.

RH soundings from RVV are used to model the fluctuations of the particle diameters and refractive index as a function of height. Mie theory then enables calculation of the particulate RHcorrected BER ratio as a function of altitude. Note that $\mathrm{RH}$ soundings and lidar measurements are acquired in the same general area but that they are not co-located. The so-calculated BER will be representative of the general $\mathrm{RH}$ structure encountered over the experimental region (MABL and, continental plume and above the plume). The small scale fluctuations of the RH field which modulates the lidar signal on a shot-to-shot basis will not be reproduced.

However, it is essential to be able to account for RH effects on the BER, especially near the surface, where the combined effects of high $\mathrm{RH}$ values and large number concentration of sea-salt particles can modify significantly the aerosol optical properties. The BER profile at $0.73 \mu \mathrm{m}$ near Sagres is shown in Fig. 9 for the RH sounding made on 6 July at noon.

Information on the MABL and plume depths is also crucial to model the BER profile. As previously discussed, these two parameters change with the distance to the shoreline (Fig. 2) and the BER profile modeled near Sagres should not be 


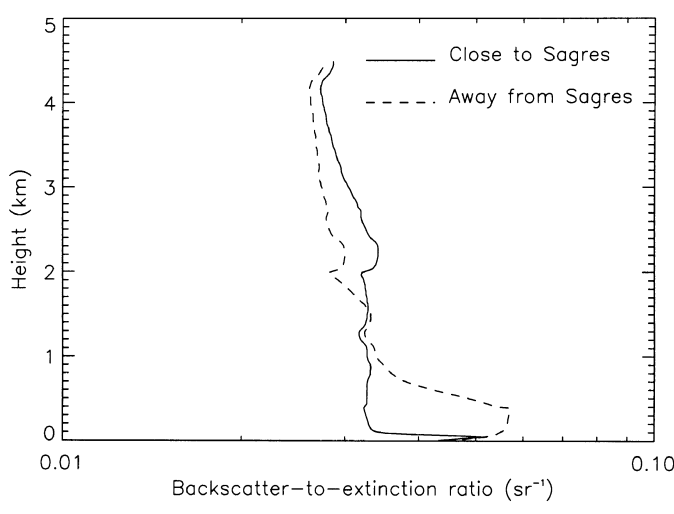

Fig. 9. Backscatter-to-extinction profile at $0.73 \mu \mathrm{m}$ near Sagres (solid line) and $250 \mathrm{~km}$ away from Sagres, near the end of the flight track F33 (dashed line), derived from the parameterized aerosol vertical distributions (Table 2). RH soundings performed at noon on 6 July and 7 July are used for the "near Sagres" and "away from Sagres", respectively.

used to derive the LPEC profiles away from the coast. Since there were no size distribution measurements available to model the BER profile directly at the other end of the leg (near $35^{\circ} \mathrm{N}$ ), we have assumed the BER in the plume did not change with latitude in order to constrain the aerosol vertical distribution. The height scales driving the number concentration decrease with altitude (Table 2) are determined iteratively by comparing LPEC profiles to modeled particulate extinction coefficient (MPEC) profiles (i.e., calculated using the parameterized number concentration profiles).

The fresh sea-salt particle number concentration in the MABL is tuned until the parameterized equivalent Angstrom coefficient matches the one derived from the nephelometer measurements at $55 \% \operatorname{RH}(\tilde{\delta}=1.0$, away from Sagres $)$. We derive a value of 1 particles $\mathrm{cm}^{-3}$ (Table 2) which is in good agreement with that derived from the relationship proposed by Smith et al. (1989).

The resulting BER near the end of the F33 flight track, at about $35 \mathrm{~N}$, is also shown in Fig. 9 (dashed line). The RH sounding made on 7 July at noon has been used to calculate this profile.

To illustrate the sensitivity of LPEC profiles to the aerosol model, we have processed the lidar data acquired near Sagres with the two BER profiles shown on Fig. 9. The LPEC profile processed with the parameterization derived near
Sagres is taken as the reference. As shown in Fig. 10, the use of an inappropriate aerosol model can be an important source of error in the lidar data analysis.

To process the lidar data from F33, we have interpolated the BER profiles obtained at each end of the leg, on a $250 \mathrm{~km}$ by $3 \mathrm{~km}$ domain (Fig. 2) with a grid size of $0.4 \mathrm{~km}$ by $0.015 \mathrm{~km}$ (equal to the lidar data horizontal and verical resolution used in this study). Therefore, a BER profile is associated to each lidar signal profile.

\subsection{Nephelometer measurements}

The reference extinction coefficient (needed to initialize the lidar inversion procedure) is obtained from in situ scattering measurements around $0.55 \mu \mathrm{m}$ made by an integrating nephelometer mounted on the ARAT. The geometry of the instrument implies that scattering coefficients are measured (Heintzenberg and Charlson, 1996). The sampled air used in this instrument was heated to maintain an $\mathrm{RH}$ below $60 \%$. Here, the sampling error on the measured scattering coefficient is estimated to be of the order of $10 \%$ in the as particles mean diameters are smaller than $0.3 \mu \mathrm{m}$ (Anderson et al., 1996).

The scattering coefficient measured at $3 \mathrm{~km}$ during the ARAT ascent is used as a reference for the inversion procedure. Since lidar measurements are made at a wavelength of $0.73 \mu \mathrm{m}$, the nephelometer-derived scattering coefficient is shifted from 0.55 to $0.73 \mu \mathrm{m}$ using the Angstrom coefficient

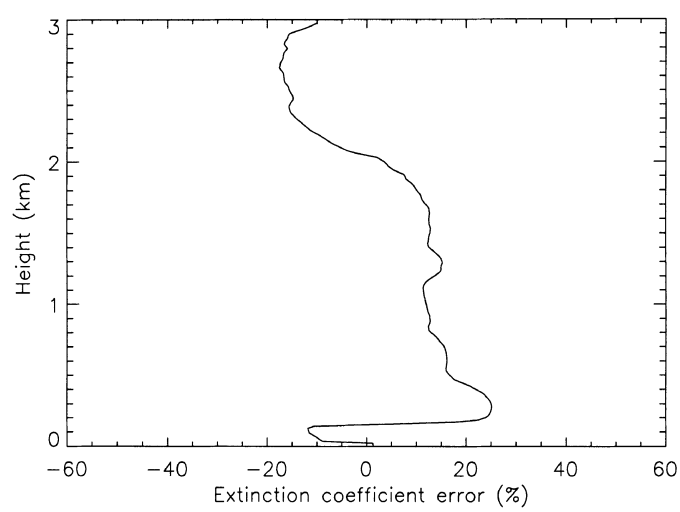

Fig. 10. Error in the extinction coefficient retrieved at $0.73 \mu \mathrm{m}$ from lidar data processed with the BER profiles shown in Fig. 9. 
profile calculated from the aerosol distribution profiles discussed in Subsection 3.1. These Angstrom coefficient profiles near Sagres and $250 \mathrm{~km}$ from Sagres are shown in Fig. 11.

\subsection{Errors on the LPEC profile}

The error in the LPEC profile is mainly caused by the uncertainty in the value of the reference extinction coefficient and in the BER profile. The latter depends on the aerosol vertical distribution parameterization. Errors related to signal detection are discarded because the signal-to-noiseratio is greater than 20 in our case.

The first source of error stems from the accuracy of the reference backscatter coefficient value used in the inversion procedure. In a forward inversion scheme, the sensitivity to errors in the reference value is increasing away from the reference altitude (Klett, 1985). Given an estimated accuracy of $10 \%$ in the extinction coefficient measured at the reference altitude, the relative error in the extinction increases to about $20 \%$ near the surface, for the range of AOD encountered on 6 July.

The uncertainty in the BER introduces an error in the extinction coefficient that will propagate away from the source as it affects the transmission calculation (Klett, 1985). We assumed an arbitrary $\pm 20 \%$ uncertainty on the fraction $f^{i}$ of aerosol in mode $i$ (see eq. (1)) for each mode to assess the sensitivity of the LPEC profiles. The BER profile derived from the parameterization summarized in Table 1 (near Sagres) is taken as the reference. The largest error on the LPEC is related to the $\pm 20 \%$

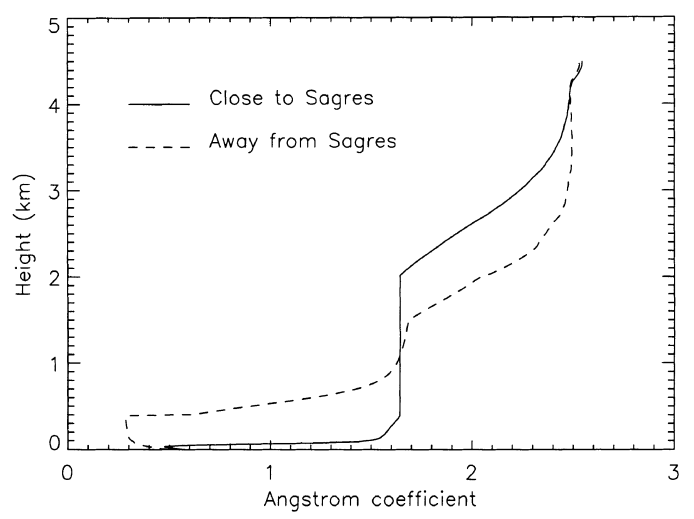

Fig. 11. Same as Fig. 9, except for the Angstrom coefficient between 0.55 and $0.73 \mu \mathrm{m}$. uncertainty in the $0.8 \mu \mathrm{m}$ mode. However, it remains smaller than $5 \%$ in the plume and in the free troposphere. At the top of the MABL it was found to be on the order of $10 \%$, and smaller below.

Since the reference-related and BER-related errors are independent, they can be summed quadratically. Therefore, errors on the LPEC values throughout the lower troposphere are mainly due to the error on the reference extinction coefficient.

\section{Closure analyses}

The scope of this section is to test the aerosol vertical distribution derived from in situ measurements by use of closure analyses on the extinction coefficient profiles and optical depth retrievals.

\subsection{Extinction coefficient closure}

A first closure is obtained by comparing MPEC profiles to LPEC profiles and nephelometer particulate extinction coefficient (NPEC) measurements made during F33 and F34. LPEC profiles are shifted from their original wavelength to $0.55 \mu \mathrm{m}$ using the Angstrom coefficient profiles shown in Fig. 11. The Angstrom coefficient profiles are calculated using the parameterized aerosol vertical distributions (Table 2) and the RH soundings (as for the BER profiles in Fig. 9).

In Fig. 12, we show the LPEC, NPEC and MPEC profiles measured near Sagres. The agreement between the LPEC and MPEC profiles is better than $25 \%$ between 0.5 and $3 \mathrm{~km}$. The difference between the profiles is related to the fact that the parameterization only reproduces the general features of the aerosol distribution as a function of height. The agreement between the LPEC and NPEC profiles is better than 25\% between 0.5 and $2 \mathrm{~km}$. Above $2 \mathrm{~km}$, NPEC measurements are too noisy. The fact that nephelometer measurements are representative of dry particles extinction is not the source of this discrepancy because, above the MABL, the atmosphere is relatively dry ( $\mathrm{RH}$ of $40 \%$ or less). Rather, the NPEC and LPEC profiles were not sampling the same part of the plume. Near the end of the flight track, an agreement better than $10 \%$ between the LPEC and MPEC profiles is obtained (Fig. 13). 


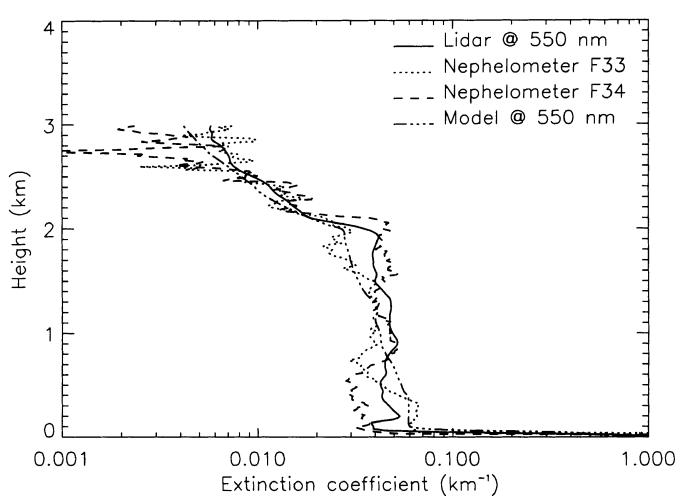

Fig. 12. Particulate extinction profile in the lower troposphere on 6 July near $37^{\circ} \mathrm{N}$. The dotted and dashed lines represents nephelometer measurements of dry particle extinction acquired shortly after take-off during F33 and F34, respectively. The lidar-derived particulate extinction coefficient (LPEC) profile at a wavelength of $0.55 \mu \mathrm{m}$ (solid line) is taken from F33. The modeled particulate extinction coefficient (MPEC) profile is given by the open symbols.

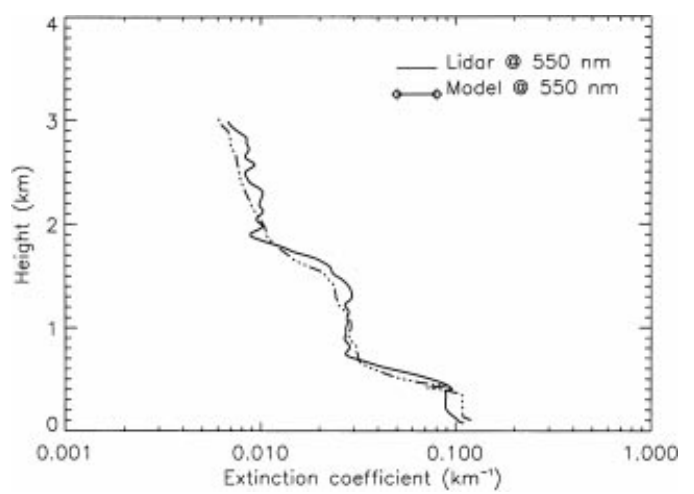

Fig. 13. Same as Fig. 12 but near $35^{\circ} \mathrm{N}$ and for the LPEC and MPEC profiles only (solid and open symbols, respectively).

\subsection{Optical depth closure using sunphotometer and Meteosat measurements}

We now compare the evolution of the AOD derived from lidar measurements with those measured by AATS-6, SIMBAD, and Meteosat radiometer on 6 July.

AATS-6 took measurements of the direct solar beam transmission from the RVV (Livingston et al., 2000). From the slant-path transmissions, spectral AOD's are retrieved at 5 wavelengths $(0.38,0.45,0.525,0.864$ and $1.020 \mu \mathrm{m})$.
In sun-viewing mode, SIMBAD also measured direct solar beam transmission, but at $0.443,0.490$, $0.560,0.670$, and $0.870 \mu \mathrm{m}$. Aerosol optical depth was deduced from total optical depth by subtracting molecular and ozone optical depths. Total column ozone from 1978-1982 Total Ozone mapping Sounder data was used to perform the ozone correction, significant at 0.560 and $0.670 \mu \mathrm{m}$.

An image of the continental plume acquired on 6 July at 1200 UTC from the visible channel (400-1100 nm) of Meteosat-4 has been used to estimate the AOD along the ARAT flight track during F33 (Fig. 14). The pixel resolution is about $30 \times 21 \mathrm{~km}^{2}$. Numeric counts (in the range 0-255) obtained in the visible channel, were converted into radiance, relying on the sensor calibration performed by Moulin et al. (1996). The optical depth at $0.55 \mu \mathrm{m}$ was retrieved over the northeastern Atlantic, using the method initiated by Dulac et al. (1992) and generalized by Moulin et al. (1997a, b). The method is applicable only under clear-sky conditions and over sea surface because the high reflectivity in the solar spectrum of clouds and land masked the aerosol contribution to the satellite signal. It is assumed that the only variable parameter in the Earth-atmosphere system over sea surface is the aerosol concentration, i.e., the aerosol optical depth (Dulac et al., 1992). The Meteosat signal results from the vertical integration of the sunlight scattered by sea surface, gas molecules and aerosols including the stratospheric contribution. In this study, stratospheric aerosols were assumed not to be present.

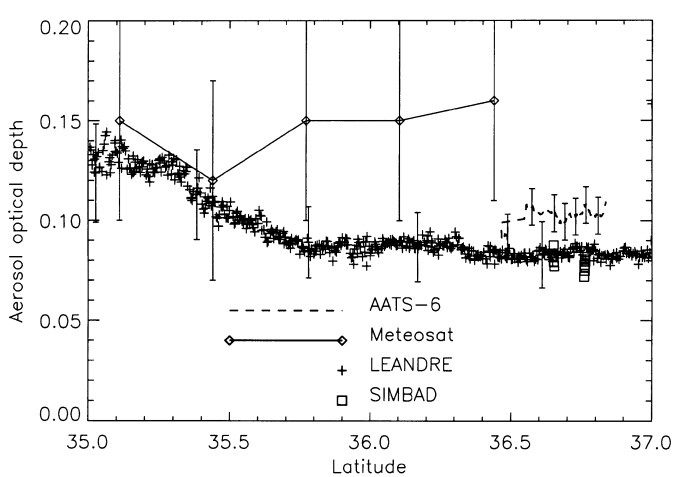

Fig. 14. Aerosol optical depth (AOD) evolution as derived from lidar (crosses), AATS-6 (solid line), SIMBAD (open squares) and Meteosat (lozenges) measurements at $0.55 \mu \mathrm{m}$. 
The algorithm for AOD monitoring over the Atlantic considers two models for the different aerosol components: water-solubles sulphate-like particles and desert dust. For the range of angles accessible to Meteosat in the Atlantic Ocean region, the desert dust and sea-salt particle optical behaviour are very similar (Paronis et al., 1998). Furthermore, the AOD retrievals were found to be rather insensitive to the aerosol model considered (those discussed by Paronis et al. (1998) and the one described in the present paper). The error associated with the AOD retrievals is of the order of $25 \%$ as estimated by Moulin et al. (1997b) in the presence of desert dust.

In Fig. 14, we compare the AOD retrieved at $0.55 \mu \mathrm{m}$ from LEANDRE 2, AATS-6, SIMBAD and Meteosat (between 0900 and 1000 UTC, between 0820 and 1200 UTC, between 1030 and 1300 UTC and at 1200 UTC, respectively). Good agreement is found in terms of evolution as a function of latitude. LEANDRE 2 and AATS-6 data are shifted from their original wavelength to $0.55 \mu \mathrm{m}$ using the equivalent Angstrom coefficient $\tilde{\delta}$ between 0.525 and $0.864 \mu \mathrm{m}$ derived from AATS-6 measurements $(\tilde{\delta}=1.31)$. SIMBAD data are interpolated to $0.55 \mu \mathrm{m}$ from the AOD's at 0.49 and $0.56 \mu \mathrm{m}$ using a $\log -\log$ scale.

We find the AATS- 6 derived AOD at $0.55 \mu \mathrm{m}$ to be equal to $0.102 \pm 10 \%$ which, given the instrumental precision, is in acceptable agreement with the value of $0.083 \pm 20 \%$ derived from lidar measurements. The SIMBAD-derived AOD, $0.079 \pm 12 \%$, is in better agreement with the lidar value.

Between 35.75 and $37^{\circ} \mathrm{N}$, values of the AOD derived from Meteosat along the F33 ARAT track are about $40 \%$ larger than those derived from the other instruments. Near the end of the track, the agreement between lidar and Meteosat AOD is within $15 \%$. Note that the best agreement is obtained in the region where the contribution of the AOD in the plume to the total AOD is smallest. Closer to Sagres, the large difference between lidar/sunphotometer and Meteosat AOD is not caused by an evolution of the aerosol content in the plume between 0900 and 1200 UTC as evidenced by AATS- 6 measurements. To provide further evidence of this, we have investigated the AOD in 4 rows of Meteosat pixels West of and parallel the F33 track. (Given the average wind speed and direction in the plume $\left(8 \mathrm{~m} \mathrm{~s}^{-1}\right.$ and NNW, respectively), the air mass sampled by the lidar has been advected West of the F33 track by approximately $100 \mathrm{~km}$ in a $3 \mathrm{~h}$ time frame which corresponds to about 4 Meteosat pixels.) The AOD was observed to be homogeneous over that area and equal to 0.15 on average.

The higher Meteosat values cannot be explained by an underestimation of the surface reflectance in the inversion scheme. First, the diffuse marine reflectance obtained from SIMBAD data was small, between 0.0038 and 0.0052 at $0.56 \mu \mathrm{m}$ and less than 0.001 at $0.67 \mu \mathrm{m}$. Second, the Meteosat geometry minimized sunglint effects. Third, wind speed was small except in the morning, with values between 2 and $7 \mathrm{~m} \mathrm{~s}^{-1}$; no whitecaps were present on the sea surface at the time of the Meteosat observation.

The difference between lidar/sunphotometer and Meteosat AOD values is thought to be caused by large uncertainties associated with the Meteosat sensitivity for small AOD's. The error associated with AOD's smaller than 0.2 is on the order of \pm 0.05 . It could also result from the presence of thin scattered clouds filling the Meteosat pixels.

\section{Spatial characterisation of the aerosol optical depth in the continental plume as observed by LEANDRE 2}

During F33, as the ARAT was flying away from the coast, lidar measurements indicate an increase of AOD as shown by Fig. 14. However, we have shown that, between 35 and $36^{\circ} \mathrm{N}$, the MABL depth and $\mathrm{RH}$ changed abruptly (i.e., the MABL deepens and $\mathrm{RH}$ increases). As a result, the MABL AOD contribution to the total AOD increases drastically.

In Fig. 15, we have plotted the AOD between 0.5 and $3 \mathrm{~km}$. This part of the AOD can be considered the contribution of the continental plume only, as the height of the MABL stays below $0.5 \mathrm{~km}$ (see Fig. 4). This AOD of the plume decreases from 0.04 near Sagres $\left(37^{\circ} \mathrm{N}\right)$ to 0.03 over the ocean, while the total AOD increased from 0.055 to 0.10 . Hence, the MABL contribution to the total AOD varies from a value of $10 \%$ near Sagres to $70 \%$ at a distance of $250 \mathrm{~km}$ from Sagres. This emphasizes the need for information on the aerosol vertical distribution when 


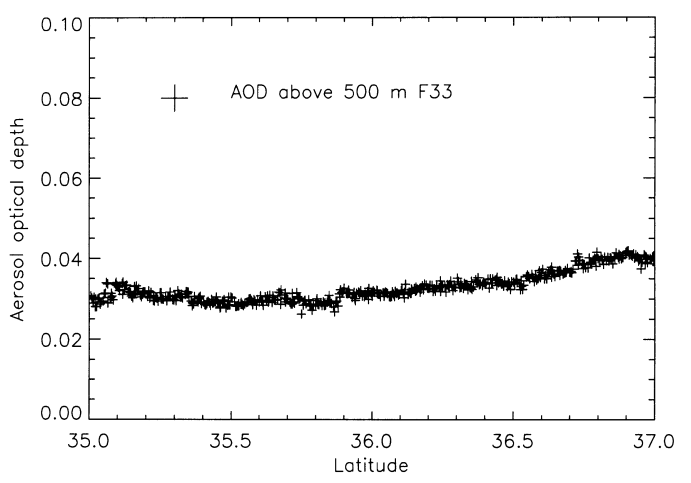

Fig. 15. Evolution of the AOD measured between 0.5 and $3 \mathrm{~km}$ as derived from lidar measurements made at $0.73 \mu \mathrm{m}$ for F33 (crosses).

attempting to identify the optical properties of anthropogenic and natural aerosol at the regional and global scale. Otherwise, large errors may occur when assessing the direct radiative forcing associated with continental aerosols.

On average, between 35 and $35.5^{\circ} \mathrm{N}$, the total AOD in the MABL breaks down as follow: $36 \%$ is due to fresh sea-salt particles, $35 \%$ to aged seasalt particles and $29 \%$ to pollution aerosol. Only $15 \%$ of the pollution aerosol contribution to the AOD is due to hygroscopic growth for an ambient $\mathrm{RH}$ increasing from 50 to $80 \%$ (i.e., the change in $\mathrm{RH}$ from the region located between between 37 and $35.5^{\circ} \mathrm{N}$ and that located between 35 and $\left.35.5^{\circ} \mathrm{N}\right)$.

\section{Conclusion}

Airborne lidar measurements of aerosol spatial distribution and extinction over the Atlantic Ocean during the 6 July 1997 European pollution outbreak of ACE-2 have been presented.

Above the continent, the continental plume top was observed to reach an altitude of $2 \mathrm{~km}$. As the plume advected over the ocean, subsidence lead to a drastic reduction of its depth. At a distance of $150 \mathrm{~km}$ from Sagres, an internal boundary layer was observed to develop up to an altitude of $0.5 \mathrm{~km}$.

Size distribution spectra measured over the ocean on-board the RVV and on-board the ARAT have been used to parameterize the aerosol vertical distribution in the experimental area. Closure on the fresh sea-salt particles number concentration (not measured otherwise) was obtained by use of AATS-6 AOD measurements. This parameterization, which is essential to the analysis of airborne lidar measurements, has been validated via closure experiments on extinction coefficient profiles and AOD.

During the studied event, AOD's retrieved from lidar measurements at $0.73 \mu \mathrm{m}$ range between 0.055 and 0.10 . The parameterized aerosol vertical distribution has been used to shift AOD retrievals from 0.73 to $0.55 \mu \mathrm{m}$ to enable comparison with other remote sensing instruments. At the latter wavelength, AOD's retrieved from lidar measurements range between 0.08 and 0.14 . An agreement better than $20 \%$ is obtained between AOD derived from lidar and sunphotometer measurements made at the same time and place over the ocean near the coast. However, large differences are observed with the AOD estimated from Meteosat imagery in the same area which are caused by sensitivity uncertainties. Another reason for this discrepancy could be the presence of thin scattered clouds filling the Meteosat pixels.

During TARFOX, Novakov et al. (1997) have shown that the soot mass fraction was negligible near the surface but increased significantly with height. The fact that, during the 6 July pollution outbreak, the lidar-derived particulate extinction coefficient and nephelometer particulate extinction coefficient profiles are in good agreement could be an indication that absorption by pollution aerosols is small and/or that soot is present in small amounts in the European pollution plume.

Lidar measurements have also been used to differentiate the contribution of different aerosol layer to the total AOD. It is shown that the AOD in the marine atmospheric boundary layer (MABL) can contribute as much as $70 \%$ of the total AOD in some regions. At $0.73 \mu \mathrm{m}$, the AOD in the continental plume was observed to diminish with the distance to the coastline from 0.04 to 0.03 .

The characterization of aerosol vertical distribution thus appears to be an important step for the analysis of aerosol optical properties at the regional and global scales. Lidars can provide accurate and spatially highly-resolved information on the layered aerosol structures in the atmosphere. The need for an accurate determination of the optical properties of anthropogenic and natural aerosols at the global scale, necessary to 
assess their overall direct and indirect radiative forcing, should benefit from such measurements.

\section{Acknowledgments}

This research is a contribution to the International Global Atmospheric Chemistry (IGAC) Core Project of the International Geosphere-Biosphere Programme (IGBP) and is part of the IGAC Aerosol Characterization Experiments (ACE). It has been supported by the Centre National d'Études Spatiales (CNES), by the Centre National de la Recherche Scientifique (CNRS) through the Programme Atmosphère Océan à Moyenne Échelle (PATOM), by the Institut National des Sciences de l'Univers (INSU) as well as by NASA and NOAA. The authors wish to thank Pr. J. Heintzenberg and Dr. D. Johnson for their financial support in the framework of CLEARCOLUMN and LAGRANGIAN activities. Finally, the authors wish to thank the Commisariat à l'Énergie Atomique (CEA) for providing the Meteosat images in the framework of the MEDUSE program (contract ENV4-CT95-0036).

\section{Appendix A}

\section{The parametrized vertical distribution of aerosol number concentration}

In the parameterization, 4 distinct layers are considered: the MABL, the MABL, the continental plume and the free troposphere. For a given mode, the total number concentration in the lower troposphere (between 0 and $3 \mathrm{~km}$, the range of altitude over which the lidar signal is processed) is separated into "surface layer", "mixed layer", "plume" and "background" components. The component is written as

$$
\begin{aligned}
& N_{\mathrm{sfl}}(z) \\
& = \begin{cases}N_{\mathrm{sf} 1}^{0} & \text { for } 0 \leqslant z \leqslant \overline{h_{\mathrm{sf} 1}}, \\
N_{\mathrm{sf} 1}^{0} \exp \left(-\frac{\left(z-\overline{h_{\mathrm{sf} 1}}\right)}{H_{\mathrm{sf} 1}}\right) & \text { for } \quad z \geqslant \overline{h_{\mathrm{sf} 1},}\end{cases}
\end{aligned}
$$

where $z$ is altitude, $\overline{h_{\mathrm{sfl}}}$ is the average top height and $H_{\text {sfl }}$ is a height scale to be determined from the measurements. The component is given by

$N_{\text {mabl }}(z)$

$= \begin{cases}N_{\text {mabl }}^{0} & \text { for } \overline{\mathrm{h}_{\mathrm{sfl}}} \leqslant z \leqslant \bar{h}, \\ N_{\text {mabl }}^{0} \exp \left(-\frac{(z-\bar{h})}{H_{\text {mabl }}}\right) & \text { for } z \geqslant \bar{h},\end{cases}$

where $\bar{h}$ is the average MABL top height and $H_{\text {mabl }}$ is a height scale to be determined from the measurements. The background component is written as

$N_{\text {Back }}(z)=N_{\text {back }}^{0} \exp \left(-\frac{(z-\bar{h})}{H_{\text {Back }}}\right)$ for $z \geqslant \bar{h}$,

where $H_{\text {Back }}$ is a height scale to be determined from the measurements. Similarly, the plume component is parameterized as

$$
\begin{aligned}
& N_{\text {Plume }}(z) \\
& = \begin{cases}N_{\text {Plume }}^{0} \exp \left(-\frac{(z-\bar{h})}{H_{\text {Plume }}}\right) & \text { for } \bar{h} \leqslant z \leqslant z_{\mathrm{T}}, \\
N_{\text {Plume }}\left(z_{\mathrm{T}}\right) \exp \left(-\frac{\left(z-z_{\mathrm{T}}\right)}{H_{\mathrm{T}}}\right) & \text { for } z \geqslant z_{\mathrm{T}},\end{cases}
\end{aligned}
$$

where $z_{\mathrm{T}}$ is the height of the top of the plume and $H_{\text {Plume }}$ and $H_{\mathrm{T}}$ are height scales to be determined from the measurements.

\section{Appendix B}

\section{The equivalent Angstrom coefficient}

The Angstrom coefficient $\delta$ is defined as:

$\delta(z)=\frac{\ln \left[\alpha_{2}(z) / \alpha_{1}(z)\right]}{\ln \left(\lambda_{1} / \lambda_{2}\right)}$,

where $\alpha_{i}$ is the total particulate extinction at wavelength $\lambda_{i}$. The equivalent Angstrom coefficient $\tilde{\delta}$ (as derived from AATS-6) is given by

$\tilde{\delta}=\frac{\ln \left(\tau_{2} / \tau_{1}\right)}{\ln \left(\lambda_{1} / \lambda_{2}\right)}$,

with

$\tau_{i}=\int_{0}^{H} \alpha_{i}(z) \mathrm{d} z$,

where $H$ is the upper altitude boundary to be 
considered (4.5 km here). Therefore, $\tilde{\delta}$ and $\delta$ are related by the following expression:

$\tilde{\delta}=\frac{\ln \left[\int_{0}^{H} \alpha_{1}(z) \mathrm{d} z\right]-\ln \left[\int_{0}^{H} \alpha_{1}(z)\left(\lambda_{2} / \lambda_{1}\right)^{-\delta(z)} \mathrm{d} z\right]}{\ln \left(\lambda_{2} / \lambda_{1}\right)}$.

Profiles of $\delta$ and $\alpha$ are derived from our para- meterization of the aerosol vertical distribution in the lower troposphere (Figs. 11, 12). The number concentration of fresh sea-salt particles (mode at $2.8 \mu \mathrm{m})$ in the MABL is adjusted so that the value of the equivalent Angstrom coefficient derived from the parameterization matches the one derived from AATS-6 measurements.

\section{REFERENCES}

Anderson, B. E. et al. 1996. Aerosols from biomass burning over the tropical South Atlantic region: distributions and impacts. J. Geophys. Res. 101, 24,117-24,137.

Anderson, T. L. et al. 1996. Performance characteristics of a high-sensitivity three-wavelength total scatter/ backscatter coefficient nephelometer. J. Atmos. Oceanic Tech. 13, 967-986.

Bates, T. S., Huebert, B. J., Gras, J. L., Griffiths, F. B and Durkee, P. A. 1994. International global atmospheric chemistry (IGAC) projects' first Aerosol Characterization Experiment (ACE 1). Overview. J. Geophys. Res. 103, 16,297-16,318.

Bates, T. S., Quinn, P., Covert, D. S., Coffman, D. J. and Johnson, D. 2000. Aerosol physical properties and controlling processes in the lower marine boundary layer: A comparison of sub-micron data from ACE-1 and ACE-2. Tellus 52B, 258-272.

Berner A., Sidla, S., Galambos, Z., Kruisz, C. and Hitzenberger, R. 1996. Modal character of atmospheric black carbon size distributions. J. Geophys. Res. 101, 19,559-19,565.

Boucher O. and Lohman, U. 1995. The sulfate-CNNcloud albedo effect: a sensitivity study using two general circulation models. Tellus B47, 281-300.

Boucher O. and Anderson, T. L. 1995. General circulation model assessment of the sensitivity of direct climate forcing by anthropogenic sulfate aerosols to aerosol size and chemistry. J. Geophys. Res. 100 26,117-26,134.

Browell, E. V. et al. 1996. Large-scale air mass characteristics observed over Western Pacific during summertime. J. Geophys. Res. 101, 1691-1712.

Chalon, J.-P. et al. 1998. Les avions franccais de recherche atmosphérique et de télédétection. La Météorologie 8, 14-44.

Chazette P., David, C., Lefrère, J., Godin, S., Pelon, J. and Mégie, G. 1995. Comparative lidar study of the optical, geometrical, and dynamical properties of stratospheric post-volcanic aerosols, following the eruptions of El Chichon and Mount Pinatubo. J. Geophys. Res. 100, 23,195-23,207.

Dulac, F., Tanré, D., Bergametti, G., Buat-Ménard, P., Desbois, M. and Sutton, D. 1992. Assessment of the African airborne dust mass over the western Mediterranean Sea using Meteosat data. J. Geophys. Res. 97, 2489-2506.

Flamant, C., Trouillet, V., Chazette, P. and Pelon, J.
1998. Wind speed dependence of atmospheric boundary layer optical properties and ocean surface reflectance as observed by backscatter lidar. J. Geophys. Res. 103, 25,137-25,158.

Hänel, G. 1976. The properties of atmospheric aerosol particles as functions of the relative humidity at thermodynamic equilibrium with the surrounding moist air. Adv. Geophys. 19, 73-188.

Hegg, D. A., Livingston, J., Hobbs, P. V., Novakov, T. and Russell, P. 1997. Chemical apportionment of the aerosol column optical depth off the mid-Atlantic coast of the United States. J. Geophys. Res. 102, 25,293-25,303.

Heintzenberg, J. and Charlson, R. J. 1996. Design and applications of the integrating nephelometer: A review. J. Atmos. Oceanic Tech. 13, 987-999.

Holben, B. N., Kaufman, Y. J., Setzer, A. W., Tanré, D. and Ward, D. E. 1991. Optical properties of aerosol emissions from biomass burning in the Tropics, BASE-A. In: Global biomass burning (ed. J. S. Levine), MIT Press, Cambridge, Mass., pp. 403-411.

Hoppel, W. A., Fitzgerald, J. W., Frick, G. M., Larson, R. E. and Mack, E. J. 1990. Aerosol size and optical properties found in the marine boundary layer over the Atlantic Ocean. J. Geophys. Res. 95, 3659-3686.

von Hoyningen-Huene, W., Schmidt, T., Herber, A. and Silva, A. M. 1998. Climate-relevant columnar aerosol parameters obtained during ACE-2 CLEARCOL$\mathrm{UMN}$ and their influence on the shortwave radiative balance. J. Aerosol Sci. 29, suppl. 1, S269-S270.

Jaenicke, R. 1993. Tropospheric aerosols. In: Aerosolcloud-climate interactions (ed. P. V. Hobbs). Academic Press, San Diego, pp. 1-31.

Johnson, D. et al. 2000. An overview of the Lagrangian experiments undertaken during the North Atlantic Regional Aerosol Characterisation Experiment (ACE-2). Tellus 52B, 290-320.

Klett, J. D. 1985. Lidar inversion with variable backscatter/extinction ratios. Appl. Opt. 24, 1638-1643.

Livingston, J. M., Kapustin, V. N., Schmid, B., Russell, P. B., Quinn, P. K., Timothy, S. B., Philip, A. D. and Freudenthaler, V. 2000. Shipboard sunphotometer measurements of aerosol optical depth spectra and columnar water vapor during ACE-2. Tellus B, this issue.

Moulin, C., Lambert, C. E., Poitou, J. and Dulac, F. 1996. Long-term (1983-1994) calibration of the 
Meteosat solar (VIS) channel using desert and marine targets. Int. J. Remote Sens. 17, 1183-1200.

Moulin, C., Guillard, F., Dulac, F. and Lambert, C. E. 1997a. Long-term daily monitoring of Saharan dust load over marine areas using Meteosat ISCCP-B2 data (I). Methodology and preliminary results for the Western Mediterranean. J. Geophys. Res. 102 $16,947-16,958$.

Moulin, C., Dulac, F., Lambert, C. E., Chazette, P., Jankowiak, I., Chatenet, B. and Lavenu, F. 1997b. Long-term daily monitoring of Saharan dust load over marine areas using Meteosat ISCCP-B2 data (II) Accuracy of the method and validation using sunphotometer measurements. J. Geophys. Res. 102 $16,959-16,969$.

Novakov, T., Hegg, D. A. and Hobbs, P. V. 1997. Airborne measurements of carbonaceous aerosols on eas coast of the US. J. Geophys. Res. 102, 30,023-30,030.

Novakov, T., Quinn, P. K. and Bates, T. S. 2000. A shipboard measurements of concentrations and properties of carboneaceous aerosols during ACE-2. Tellus 52B, 228-238.

Neusüß, C., Weise, D., Birmili, W., Wex, H., Weidensohler, A. and Covert, D. 2000. Size-segregated chemical, gravimetric, and number distribution derived mass closure of the aerosol in Sagres, Portugal during ACE-2. Tellus $\mathbf{B}$, this issue.

Paronis, D., Dulac, F., Chazette, P., Hamonou, E. and Liberti, G. L. 1998. Aerosol optical thichkness monitoring in the Mediterranean. J. Aerosol Sci. 29, suppl. 1, S671-S672.

Quaglia P. et al. 1996. The airborne water vapor lidar LEANDRE 2: design, realization, tests and first validation. In: Advances in atmospheric remote sensing with lidar (ed. A. Ansmann, R. Neuber, P. Rairoux and U. Wandinger). Springer, Berlin, pp. 297-300.

Quinn, P. K., Bates, T. S., Coffman, D. J., Miller, L. T.,
Johnson, J. E. and Covert, D. S. 2000. A comparison of aerosol chemical and optical properties from the first and second Aerosol Characterization Experiment. Tellus 52B, 239-257.

Raes, F., Bates, T. S., McGovern, F. M. and Van Liedekerte, M. 2000. The second Aerosol Characterization Experiment (ACE-2): general overview and main results. Tellus 52B, 111-126.

Russell, P. B. and Heintzenberg, J. 2000. An overview of the ACE-2 clear sky column closure experiment (CLEARCOLUMN). Tellus 52B, 463-483.

Russell, P. B., Hobbs, P. V. and Stowe, L. L. 1999 Aerosol properties and radiative effects in the UIS mid-Atlantic haze plume: an overview of the tropospheric aerosol radiative forcing observational experiment (TARFOX). J. Geophys. Res. 104, 2213-2222.

Scheele, M. P., Siegmund, P. C. and Van Velthoven, P. F. J. 1996. Sensitivity of trajectories to data resolution and its dependence on the starting point: in or outside a tropopause fold. Meteor. Appl. 3, 267-273.

Sloane, C. S. 1984. Optical properties of aerosols of mixed composition. Atmos. Env. 18, 871-878.

Smith, M. H., Consterdine, I. E. and Park, P. M. 1989. Atmospheric loadings of marine aerosol during a Hebridean cyclone. Quart. J. Roy. Meteorol. Soc. 115, 383-395.

Tegen I. and Lacis, A. A. 1996. Modeling of particle size distribution and its influence on the radiative properties of mineral dust aerosol. J. Geophys. Res. 101, 19,237-19,244.

Verver, G., Raes, F., Vogelezang, D. and Johnson, D 2000. The second Aerosol Characterization Experiment (ACE-2): Meteorological and chemical context. Tellus 52B, 126-140.

Winker, D. M., Couch, R. H. and McCormick, M. P. 1996. An overview of LITE: NASA's lidar in-space technology experiment. Proc. IEEE 84, 164-180. 